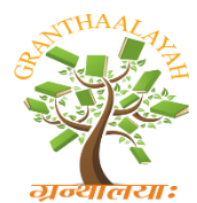

\author{
INTERNATIONAL JOURNAL OF R
GRANTHAALAYAH \\ A knowledge Repository
}

Science

\title{
SOIL WORMS POPULATION IN VARIOUS LITTLE QUALITY (C, N, C / N, LIGNIN, AND POLYPHENOL) (CASE STUDY ON AGROFORESTRY LAND IN KELIMUTU NATIONAL PARK, ENDE REGENCY - INDONESIA)
}

\author{
Agustinus JP Ana Saga ${ }^{1}$, Heny M.C. Sine ${ }^{2}$, Laurensius Lehar *3 \\ ${ }^{1}$ Faculty of Agriculture, University of Flores, Ende, Indonesia \\ $2, * 3$ Department Food Crops and Horticulture, State Agricultural Polytechnic of Kupang, \\ Indonesia
}

\begin{abstract}
The agricultural business that is applied to the agroforestry system in Kelimutu National Park causes differences in the quality of organic matter of plants and earthworm populations, which have consequences for soil environmental services. The purpose of this study is to evaluate the earthworm population and the quality of plant organic matter in various agroforestry systems, intensive agriculture, and secondary forests. Sampling of organic matter from plants and earthworms was carried out in January - July 2016 (in the rainy season) in Agroforestry land: Clove (AF - CK), Cocoa (AF - KK), Candlenut (AF - KM), Coffee (AF - KM) ) compared to intensive agricultural land (monoculture vegetable crops) and secondary forests (SPL-HS), with 3 times repetition. Variables observed were in addition to the number of earthworms found and biomass worms (monolith sampling), also observed the quality of plant organic matter (C (Walkley and black), N (Kjeldahl), Lignin, and Polyphenol (Goering and Van Soest)) (Quadrants). The survey results show that the population of earthworms in SPL-AF is as low as the population in SPL-HS, an average of $3 \mathrm{~m}-2$, while in the SPL-PI the average is only $0.24 \mathrm{~m}-2$. Earthworm biomass in AF is about $69 \%$ smaller than worms found in SPL-HS; average earthworm biomass in SPL-AF $15 \mathrm{gm}-2$ while in SPL-HS an average of $47 \mathrm{gm}-2$; and the smallest worm biomass found in SPL-PI averaging around $2.3 \mathrm{gm}-2$. The average quality of organic matter of C-org plants in all SSTs was $38 \%$ to $50 \%$, the highest C-org content of AF-CK, AF-KP and SPL-HS were significantly different $(\mathrm{p}<0.05)$ with $\mathrm{C}$ levels that were others $(39 \%$ on average). The $\mathrm{N}$ and lignin levels of all plant organic matter are the same (P>0.05), the average is $1.36 \%$ and $41.13 \%$, respectively. The $\mathrm{C} / \mathrm{N}$ ratio in $\mathrm{AF}-\mathrm{CK}$ and $\mathrm{HS}$ is the same at an average of $52.78 \%$ or 58 times higher than $\mathrm{AF}-\mathrm{KK}, \mathrm{AF}-\mathrm{KM}$, and $\mathrm{AF}-\mathrm{KP}$, the average is $31.11 \%$ The polyphenolic levels of different plant organic matter significant $(\mathrm{p}<0.05)$ between SPL. The highest levels of polyphenols were on average $17.5 \%$ found in plant organic matter AF - CK and SPL - HS, while plant organic matter in other fields averaged $3.4 \%$. Plant organic matter with polyphenol content $>2 \%$ will slow decay.
\end{abstract}

Keywords: Earthworm Population; Earthworm Biomass; Litter Quality; Agroforestry. 
Cite This Article: Agustinus JP Ana Saga, Heny M.C. Sine, and Laurensius Lehar. (2020). "SOIL WORMS POPULATION IN VARIOUS LITTLE QUALITY (C, N, C / N, LIGNIN, AND POLYPHENOL) (CASE STUDY ON AGROFORESTRY LAND IN KELIMUTU NATIONAL PARK, ENDE REGENCY-INDONESIA)." International Journal of Research - Granthaalayah, 8(1), 124-130. https://doi.org/10.29121/granthaalayah.v8.i1.2020.259.

\section{Introduction}

Indicator of soil fertility can be seen from the biological nature (the presence of earthworms) (Sagita et al., 2014). The changing nature of soil biology depends on the application of the selected agricultural land management system. According to (Giller et al., 1996) Management of agricultural land which is monoculture affects the earthworm population density of $85 \mathrm{~m}-2$, but in mixed gardens as much as 150 m-2 or $56 \%$ higher (Hairiah et al., 2004, ) This is due to the diversity of plants that are planted low, so it directly affects the quality of litter which is an organic plant material (Dewi et al., 2006).

As a food source for earthworms, plant organic matter is considered important, it is not only quantity but the quality that can inhibit the population of earthworms. like $\mathrm{C}, \mathrm{N}, \mathrm{C} / \mathrm{N}$ ratio, Lignin, and Polyphenol. (Setiawan, et al., 2003.) Different chemical contents allegedly can affect earthworm populations with different decomposition rates, the results can be in the form of nutrients and other mineral elements. Earthworms are decomposers whose populations are related to the availability of plant organic matter (Fragoso et al., 1999).

The fast and slow process of decomposition of plant organic matter is influenced by the C, N, C / $\mathrm{N}$ ratio, Lignin and Polyphenol (Setiawan. et al., 2003). The higher these elements will slow down the decomposition process (Hairiah et al., 2006a). This study aims to evaluate the differences in the quality of organic matter of plants against earthworm populations in agroforestry land in the buffer zone of the Kelimutu National Park.

\section{Material and Method}

The experiment was conducted in a buffer zone of the National Park. Kelimutu, Kelimutu District, Ende Regency. Identification and quantification of earthworms as well as the analysis of plant organic matter variables are carried out in the Lab. Biology and Chemistry Department of Soil, Faculty of Agriculture, Brawijaya university, Malang- Indonesia.

The materials used are clean water, $70 \%$ alcohol, and $4 \%$ formalin to clean and preserve earthworms, analysis of plant organic matter content used equates, potassium carbonate (K2Cr2O7), sulfuric acid (H2SO4), iron sulfate (FeSO4) $0.5 \mathrm{~N}$, mixed salt $\mathrm{Se}, \mathrm{NaOH}, \mathrm{Na} 2 \mathrm{CO} 3$, $17 \%$, raw HCL, K2SO4. The instrument used is a binocular microscope, petri dish, skewed, sorting tray, and worm identification key soil. This experiment used a nested sampling design with six treatments and three replications. 

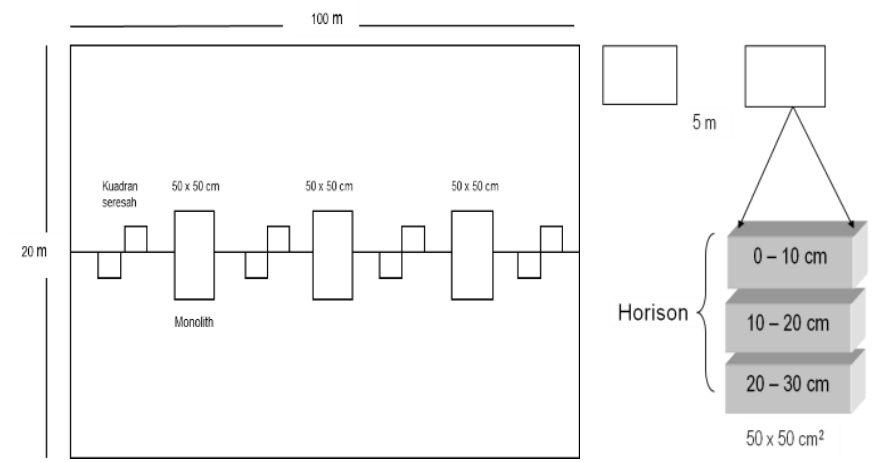

1.determine the sample along the $25 \mathrm{~cm}$ divided by 3 boxes with a distance of $5 \mathrm{~m}$ each

2. formation and separation of the monolith from the soil

3. clean litter from the soil surface and clean 3-4 soil layers at a depth of $10 \mathrm{~cm}$

4. earthworm separation manually carried out on trays and stored on sample bottles and preservatives (alcohol) were

5. performedlaboratory identification

Figure 1: Plot design and sampling of plant organic matter and worm monoliths.

The overall plot area is $100 \mathrm{~m} \chi 20 \mathrm{~m}, 3$ monolith sampling worms measuring $50 \chi 50 \mathrm{~cm}$, depth $0-30 \mathrm{~cm}, 4$ quadrants of plant-sized organic material $(0.5 \mathrm{~m}-2)$, earthworms explored by method hand sorting (Anderson and Ingram, 1993) are cleaned and preserved using 70\% alcohol, 4\% formalin, and calculated population, biomass, density and then identified according to species to determine species diversity. Plant organic material from each quadrant was taken in the same plot in the analysis of the content of C, N, C / N ratio, Lignin and Polyphenol by the Walkley-Black, Kjeldahl, and Follin-Denis methods (Hairiah et al., 2006).

Data from the identification and quantification of population, density, and diversity of earthworms were analyzed by ANOVA and followed by a 95\% DMRT test, diversity index was calculated by the Shannon winner equation:

$$
H=-\sum(P i \cdot \ln P i)
$$

Note: H: diversity index

Pi: number of individual species or groups of fauna in a community per total number of species (literature ...)

\section{Results and Discussion}

Plant Organic Material Quality (C, N, Lignin, and Polyphenol)

Average C-org levels of plants in all SPL range from $38 \%$ to $50 \%$, the highest $\mathrm{C}$ content of AF $\mathrm{CK}, \mathrm{AF}-\mathrm{KP}$ and SPL - HS were significantly different ( $\mathrm{p}<0.05)$ with other $\mathrm{C}$ levels (average $39 \%)$. The levels of $\mathrm{N}$ and lignin content of all plant organic matter were the same (P>0.05), on average respectively $1.36 \%$ and $41.13 \%$. The polyphenolic levels of plant organic matter were significantly different $(\mathrm{p}<0.05)$ between SSTs. The largest polyphenol levels averaged $17.5 \%$ were found in the AF-CK and SPL-HS litter, while plant organic matter in other fields averaged $3.4 \%$ (Table 1). Plant organic matter with polyphenol content $>2 \%$ will slow decay (Hairiah et al., 2006). 


\begin{tabular}{|l|l|l|l|l|l|}
\hline \multirow{2}{*}{ SPL } & Tot.Corg & Tot. $\mathbf{N}$ & C/N & L & P \\
\cline { 2 - 6 } & $\ldots \ldots \ldots \ldots \% \ldots \ldots .$. & \multicolumn{4}{|c|}{} \\
\hline AF-CK & $50,05 \mathrm{c}$ & $1,01^{\mathrm{TN}}$ & $54,67 \mathrm{~b}$ & $28,83^{\mathrm{TN}}$ & $15,08 \mathrm{c}$ \\
\hline AF-KK & $38,35 \mathrm{a}$ & 1,11 & $38,22 \mathrm{a}$ & 25,28 & $3,02 \mathrm{ab}$ \\
\hline AF-KM & $39,51 \mathrm{ab}$ & 1,29 & $35,33 \mathrm{a}$ & 28,63 & $2,72 \mathrm{a}$ \\
\hline AF-KP & $40,48 \mathrm{abc}$ & 2,28 & $19,78 \mathrm{a}$ & 28,72 & $4,57 \mathrm{ab}$ \\
\hline HS & $49 \mathrm{bc}$ & 1,12 & $50,89 \mathrm{~b}$ & 22,94 & $20,48 \mathrm{c}$ \\
\hline Sed & 0.23 & 6.19 & 1.19 & 3.63 & 2.50 \\
\hline
\end{tabular}

Description:

1) $\mathrm{SPL}=$ Land use system, AF.CK = Clove Agroforestry, AF. KK = Cocoa Agroforestry, AF. KM = Agroforestry Candlenut, AF. KP = Coffee Agroforestry, HS = Secondary Forest, PI = Intensive Agriculture, BK = Litter Dry Weight, L = Lignin, P = Polyphenol

2) Numbers followed by the same alphabet show no significant difference according to the results of the $5 \%$ level test, sed $=$ standard deviation error

\section{Earthworms}

\section{Population of Earthworms (P) (tail $\left.\mathbf{m}^{-2}\right)$}

Earthworm populations differ significantly $(\mathrm{p}<0.001)$ between SPL and between depths in SPLHS and SPL-AF Earthworm populations tend to be the same as the average of 3 tails $\mathrm{m}^{-2}$ whereas SPL-HS was significantly different $(\mathrm{p}<0.001)$ from SPL-PI, or 91.6\% more in SPL-HS than in SPL-PI. For earthworm populations in the SPL-AF only found $8.4 \%$ or the average population of $2 \mathrm{~m}^{-2}$.

Table 2 Earthworm populations predominate at a depth of $0-10 \mathrm{~cm}$ in each SPL compared to 10$20 \mathrm{~cm}$ and $20-30 \mathrm{~cm}$ in depth. The average number of earthworms found in the depths of $0-10 \mathrm{~cm}$ and 10-20 cm were $2 \mathrm{~m}^{-2}$ and $0.07 \mathrm{~m}^{-2}$ respectively, while at a depth of $20-30 \mathrm{~cm}$ no earthworms were found. The reduced population of earthworms in the subsoil is thought to be due to the reduced availability of feed and air circulation. (Hairiah et al., 2004)

\section{Earthworm Biomass (B) $\left(\mathrm{g} \mathrm{m}^{-2}\right)$}

Earthworm biomass in each SPL showed very significant differences $(\mathrm{P}<0.001)$, the highest earthworm biomass found in the SPL-HS average was $47.4 \mathrm{~g} \mathrm{~m}^{-2}$ or $31 \%$ higher than the earthworm biomass in SPL-AF 14, $9 \mathrm{~g} \mathrm{~m}^{-2}$ whereas in SPL-PI earthworm biomass is $69 \%$ smaller than in SPL-HS or around $2.27 \mathrm{~g} \mathrm{~m}^{-2}$ or 20 times lower than SPL-HS and 6 times less than earthworm biomass in SPL - AF. The biomass: population (B / P) ratio was not significantly different $(\mathrm{P}>0.05)$ between SPL, the mean for B / P was 0.42 (Table 2)

Table 2: Population, biomass and biomass ratios \& earthworm populations Earthworm

\begin{tabular}{|l|c|c|c|}
\hline SPL & $\begin{array}{c}\text { Earthworm population } \\
(\mathbf{P})\left(\text { tails } \mathbf{~ m}^{-\mathbf{2}}\right)\end{array}$ & $\begin{array}{c}\text { Earthworm biomass }(\mathbf{B}) \\
\left(\mathbf{g ~ m}^{-\mathbf{2}}\right)\end{array}$ & $\begin{array}{c}\text { Biomass ratio: } \\
\text { population }(\mathbf{B} / \mathbf{P})\end{array}$ \\
\hline AF-CK & $3,88 \mathrm{bc}$ & $22,62 \mathrm{~d}$ & $0,28 \mathrm{a}$ \\
\hline
\end{tabular}




\begin{tabular}{|l|c|c|c|}
\hline AF-KK & $2,02 \mathrm{abc}$ & $11,42 \mathrm{bc}$ & $0,28 \mathrm{a}$ \\
\hline AF-KM & $1,49 \mathrm{ab}$ & $11,01 \mathrm{~b}$ & $0,84 \mathrm{a}$ \\
\hline AF-KP & $2,05 \mathrm{abc}$ & $14,38 \mathrm{c}$ & $1,12 \mathrm{a}$ \\
\hline HS & $5,17 \mathrm{c}$ & $47,42 \mathrm{e}$ & $0,75 \mathrm{a}$ \\
\hline P.I & $0,25 \mathrm{a}$ & $2,27 \mathrm{a}$ & $0,65 \mathrm{a}$ \\
\hline Average & 2 & 18 & 0,65 \\
\hline s.e.d & 0,30 & 2,47 & 0,14 \\
\hline Soil depth & & & \\
\hline 0 - 10cm & $2 \mathrm{~b}$ & $18.19 \mathrm{~b}$ & $0,41 \mathrm{a}$ \\
\hline $\mathbf{1 0}-\mathbf{2 0} \mathbf{c m}$ & $0.07 \mathrm{a}$ & $0.67 \mathrm{a}$ & $0,21 \mathrm{a}$ \\
\hline $\mathbf{2 0}$ - 30cm & $0 \mathrm{a}$ & $0 \mathrm{a}$ & $0,03 \mathrm{a}$ \\
\hline Average & 0.69 & 6.29 & 0,22 \\
\hline s.e.d & 0,21 & 1,74 & 0,10 \\
\hline
\end{tabular}

Description: SPL $=$ Land Use System, AF-CK = Clove Agroforestry, AF-KK = Cocoa Agroforestry, AF-KM = Candlenut Agroforestry, AF-KP = Coffee Agroforestry, HS = Secondary Forests, PI = Intensive Agriculture, Sed = standard deviation error, Figures followed by the same alphabet indicate no significant difference according to the results of the test level 5\%

\section{Diversity, Density, and INP of Earthworms}

The diversity of earthworms is significantly different between land uses. The average diversity of earthworms ( $\mathrm{H}$ ') reaches 0.88 ; Index $\mathrm{R}=0.34$; and Index $\mathrm{E}=0.92$. Earthworm importance value index in six land-use systems AF - CK, AF - KK, AF - KM, AF - KP, SPL - H and SPL - PI where the importance value index describes the ecological level of a species in an earthworm community. The highest importance value index means the level of density, dominance, and spread of earthworms tends to be more able to adapt to environmental conditions (Narayana et al., 2016). In each of the AF-CK, AF-KK, AF-KM, AF-KP, SPL-H, and SPL-PI land-use systems in this study the highest Importance Value Index was the Megascolex type earthworm in the AF-land use system KP namely (77.65\%), Perithima earthworms (77.49\%) in SPL-PI, Pontoscolex in AF-KK (66.58\%), AF-KM (57.17\%) AF-CK (56.92\%) and $\mathrm{H}(42.10 \%)$ whereas the type of lumbricus is only spread in SPL-H (32.37\%) and AF-CK (6.66\%) (Table 3).

Table 3: Relative Frequency, Relative Density, and Important Value Index in each SPL

\begin{tabular}{|l|l|l|l|l|}
\hline SPL & Species & FR\% & KR \% & INP \% \\
\hline AF-CK & Pontoscolex & 9,26 & 47,66 & 56,92 \\
\cline { 2 - 5 } & Megascolex & 8,33 & 48,46 & 56,79 \\
\cline { 2 - 5 } & Lumbricidae & 2,78 & 3,89 & 6,66 \\
\hline \multirow{4}{*}{ AF-KK } & Pontoscolex & 8,33 & 58,24 & 66,58 \\
\cline { 2 - 5 } & Megascolex & 7,41 & 20,22 & 27,63 \\
\cline { 2 - 5 } & Prithima & 7,41 & 21,54 & 29,87 \\
\cline { 2 - 5 } & Lumbricidae & 29,87 & 0,00 & 0,00 \\
\hline \multirow{2}{*}{ AF-KM } & Pontoscolex & 4,63 & 52,54 & 57,17 \\
\cline { 2 - 5 } & Megascolex & 9,26 & 47,46 & 56,72 \\
\hline AF-KP & Pontoscolex & 13,89 & 28,85 & 42,74 \\
\hline
\end{tabular}




\begin{tabular}{|l|l|l|l|l|}
\hline \multirow{4}{*}{ HS } & Megascolex & 10,19 & 67,46 & 77,65 \\
\cline { 2 - 5 } & Prithima & 2,78 & 3,69 & 6,47 \\
\cline { 2 - 5 } & Pontoscolex & 14,81 & 27,28 & 42,10 \\
\cline { 2 - 5 } & Megascolex & 10,19 & 31,54 & 41,73 \\
\cline { 2 - 5 } & Prithima & 10,19 & 17,14 & 27,32 \\
\cline { 2 - 5 } & Lumbricidae & 8,33 & 24,04 & 32,37 \\
\hline PI & Pontoscolex & 2,78 & 22,81 & 25,58 \\
\cline { 2 - 5 } & Megascolex & 1,85 & 5,26 & 7,12 \\
\cline { 2 - 5 } & Prithima & 5,56 & 71,93 & 77,49 \\
\hline
\end{tabular}

Description: $\mathrm{SPL}=$ System Land Use, AF-CK = Agroforestry Cloves, AF-KK = Agroforestry Cocoa, AF-KM = Candlenut Agroforestry, AF-KP = Coffee Agroforestry, SPL-HS = Secondary Forest, PI = Intensive Agriculture, FR = Relative Frequency, KR = Relative Density, INP = Important Value Index.

\section{Conclusion}

1) Quality of plant organic matter: C - organics - each SPL is different, in AF - CK (50.05\%) 1 times higher than AF - KK (38.35\%). Total N and Lignin in each SPL were the same $(1.36 \%)$ and $(26.88 \%)$. C / N ratio is different in each SPL. (54.67\%) in AF - CK, or 36\% higher than (19.78\%). Polyphenols in each SPL were significantly different $(20.48 \%)$ in HS or 7 times higher than AF-KM (2.72\%).

2) The population of earthworms in SPL-HS and SPL-AF is equal to $\left(3 \mathrm{~m}^{-2}\right)$. or $91.6 \%$ more in SPL-HS than in SPL-PI. The average earthworm population in the SPL-AF was found to be $8.4 \%$ or $2 \mathrm{~m}^{-2}$ tails. In soil depth $0-10 \mathrm{~cm}$ and $10-20 \mathrm{~cm}$ Earthworm populations were found to be an average of $2 \mathrm{~m}^{-2}$ tails and $0.07 \mathrm{~m}^{-2}$ tails while in the depths of 20-30 $\mathrm{cm}$ earthworms were not found. Earthworm biomass in SPL - HS averaged $47.4 \mathrm{~g} \mathrm{~m}^{-2}$ or $31 \%$ higher than the earthworm biomass in SPL - AF 14, $9 \mathrm{~g} \mathrm{~m}^{-2}$. in SPL-PI $69 \%$ smaller than in SPL-HS or about $2.27 \mathrm{~g} \mathrm{~m}^{-2}$ or 20 times lower than SPL-HS and 6 times less than earthworm biomass in SPL-AF. The biomass: population (B / P) ratio was not significantly different $(\mathrm{P}>0.05)$ between SPL, the mean for B / $\mathrm{P}$ was 0.42 .

3) The diversity of earthworms is significantly different between land uses. The average diversity of earthworms $\left(H^{\prime}\right)$ reaches 0.88 ; Index $R=0.34$; and Index $E=0.92$.

\section{Conflict of Interest}

The authors declared that the present study was performed in the absence of any conflict of interest".

\section{Acknowledgments}

Thank you to friends who have helped during the research activities. The results of this study are dedicated to the development of science. 


\section{Author Contributions}

AJPAS and HMCS design and conduct research, data collection, data analysis and also manuscript writing. LL designs and conducts research, reviewing manuscripts and submit manuscripts.

\section{References}

[1] Anderson J. M., and Ingram, J. S. I., (eds) (1993) Tropical Soil Biology and Fertility: A Handbook of Methods, $2^{\text {nd }}$ edition, CAB International, Wallingford

[2] Dewi, W. S., Yanuwiyadi, B., Suprayogo, D. dan Hairiah, K. 2006. Alih guna hutan menjadi lahan pertanian: (1) Dapatkah sistem agroforestri kopi mempertahankan diversitas cacing tanah di Sumberjaya? Agrivita 28 (3): 27-54

[3] Fragoso, C., et al. 1999. Earthworm communities of tropical agroecosystems: origin, structure and influences of management practices. In Earthworm Management in Tropical Agroecosystems, ed. P. Lavelle, L. Brussaard, and P. Hendrix, 27-55. New York: CABI Publishing.

[4] Giller K. E., Beare M. H., Lavelle P., Izac A. M. N., Swift, M.J. 1996. Agricultural intensification, soil biodiversity and agroecosystem Fungction, Applied Soil Ecology

[5] Hairiah K., Suprayogo, D., Widianto, Berlian, Suhara, E., Mardiastuning, A., Widodo, R.H., Prayogo, C., Rahayu, S., 2004. Alih guna lahan hutan menjadi lahan pertanian: ketebalan seresah, populasi cacing tanah dan makroporositas tanah. Agrivita 26 (1): 68 - 80.

[6] Hairiah K., Sulistyani, H., Suprayogo, D., Widianto, Purnomosidhi P., Widodo R.H., dan van Noordwijk, M. 2006a. Litter layer residence time in forest and coffe agroforestry system in sumberjaya, West Lampung. Forest Ecology and Management 224 (2006) 45 - 57.

[7] Hairiah K., Subekti Rahayu, dan Berlian, 2006b. Layanan Lingkungan Agroforestri Berbasis Kopi: Cadangan karbon dalam biomasa pohon dan bahan organik tanah (studi kasus dari Sumberjaya, Lampung Barat), Agrivita 28 (3): 68 - 80

[8] Narayanan S. Prasanth, S. Sathrumithra, G. Christopher, A.P. Thomas, \& J.M. Julka, 2016. Current distribution of the invasive earthworm Pontoscolexcorethrurus (Müller, 1857) after a century of its first report from Kerala state, India, Budapest, 47 (1) : 101-107

[9] Nilawati S, Dahelmi, Nurdin J, 2014, The Earthworms Species (Oligochaeta) at Lembah Anai Nature Reserve West Sumatera Jurnal Biologi Universitas Andalas, 3 : 087 - 091.

[10] Setiawan Y, Sugiyanto, Wiryanto, 2003, Relationship of soil macrofauna and mesofauna populations with content of $\mathrm{C}, \mathrm{N}$, polyphenols, and ratio of $\mathrm{C} / \mathrm{N}$ and polyphenols/ $\mathrm{N}$ plant organic matter, BioSMART, Volume 5, Nomor 2, Halaman: 134 - 137

\footnotetext{
*Corresponding author.

E-mail address: laurensius1 @yahoo.co.id
} 